\title{
The Role of Kisspeptins (KiSS-1) in Breast Cancer Therapy: the Essential Kiss of Life
}

\author{
Abhijit Chakraborty, Jayasri Basak, Ashis Mukhopadhyay \\ Dept. of Molecular Biology, Netaji Subhas Chandra Bose Cancer Research Institute, 16 A Park Lane, \\ India \\ abhijit.drems@gmail.com
}

The most common malignancy among Indian women is breast cancer. Patient's ages ranging between 35 - 40 yrs old at diagnosis are usually considered as the endangered population [1].Breast cancer in women below 40 years is not a usual condition. However, a sudden increase in the incidence of breast cancers in premenopausal women has been reported from several countries. Though adjuvant combination chemotherapy has made immense progress, still about $50 \%$ of all women with resected early breast carcinoma suffer from relapse [2]. Systemic dissemination of tumour cells results into most of breast cancer-related deaths rather than primary tumour growth. Detachment from the primary site, survival in the circulation, attachment to and invasion of distant tissues (intravasation), proliferation and angiogenesis at the secondary sites (extravasation) are the various steps which has to take place for the metastatic spread of malignant cells [3].This mechanisms of metastasis development have been studied for several years.

Hence there is both a necessity and shear interest in studying the metastasis suppressor genes which influences the anti-metastatic mechanism. Extensive research over the last few years have succeeded in identifying few metastasis suppressor genes (MSG) which may block any one of these steps and thus inhibit the formation of metastasis without affecting tumorigenicity or primary tumour growth [4]. There are several metastasis suppressor genes which aids in guiding specific therapeutic strategies for cancer which includes gene transfer, induction of previously suppressed gene sis suppressor genes and signaling pathways.

Lee et al identified and cloned such a metastasis suppressor gene and named it as KISS1 [6]. KISS1 have been recognized to be responsible for tumour cell invasive and migratory properties without affecting their tumourigenicity[7]. It has 4 exons and is located on short arm of chromosome 1 (1q32). Of the four exons exon 2 and 3 are coding exons. The KiSS1 gene codes for 145 amino acid polypeptide (Kp-145) [8],but shorter kiss peptins (Kp) with 10, 13, 14 or 54 amino acid residues have also been discovered $[9,10]$. Kp-54, also termed 'metastin', is also a product from form of $\mathrm{Kp}-145$ [11].

It has been reported that KISS1 gene have also influenced many other human malignant tumours which includes breast [12], esophageal [13] and gastric cancers [14].It has been shown to act as a potent anti-metastatic agent either by treatment using synthesized KISS1 peptide or exogenous expression in metastasized cells $[15,16]$. Expression of KiSS1 like other metastasis suppressor genes cannot be traced completely. It influences other cancer through unidentified pathways. [17].

KiSS1 is the only gene which binds to a G-protein coupled receptor (Kisspeptin receptor (KISS1R),also known as GPR54) and gets activated later in the metastatic cascade and prevents growth of metastatic deposit, on contrary to early metastasis suppressor genes[Non metastasis genes (Nm23, KAI1)] that suppress cell detachment and migration from the primary tumor [18]. Increase in tumor invasion might be due to homozygous deletion, promoter methylation, or mutation of KiSS-1 gene. Similar results were also reported by Sanchez-Carbayo et al. [19]. Shengbing et al. [20]. According to them the KiSS-1 gene plays a vital role in tumor invasion as well as in intra-hepatic metastasis and distance metastasis by down regulation of KiSS-1. The first evidence that KISS1 expression is elevated in patient breast tumors was shown in a study by Martin and colleagues [21]. According to Martin et al node-positive tumors had elevated level of KISS1 mRNA expression than in 
node-negative ones and the said protein expression increased with tumor grade as determined by quantitative-PCR analysis and immunohistochemistry, respectively. Moreover, they also established that patients with metastatic disease had elevated levels of KISS1 expression than healthy individuals, and that this associated with poor patient prognosis. A rise inKISS1R mRNA expression in nodepositive tumors was observed, although this was not statistically significant. Other reports indicate that KISS1mRNA and protein expression is absent innode-positive tumors, and found a significant negative correlation with axillary lymph node involvement [22].KISS1 expression was found not to be associated with genes that regulate cell-cycle and proliferation such as HER2, VEGF and p53. Patients diagnosed with primary breast cancer have significantly higher KISS1mRNA and protein expression than compared with breast tumors that metastasized to the brain [23,24].In fact, a significant down-regulation ofKISS1 expression has been reported in brain metastatic lesions, compared to primary ductal carcinomas and this correlated with immunohistochemical analysis of KISS1 protein levels. Thus, these studies support the anti-metastatic role of KISS1.The analysis of patient samples, factors have to be taken into consideration such as whether the patients had received chemotherapy, the age of the women (pre- versus post-menopausal) and the genetic diversity of the patient population. These factors are not always considered or included as part of the analysis. Interestingly, these later studies did not examine KISS1R association with axillary lymph node involvement and thus, further researches are required to investigate alteration in the expression profile of KISS1 and KISS1R in patients at the gene and protein level. Nowadays studies have revealed that estrogen receptor (ER) status of breast tumors has to be taken into account since expression and function of both KISS1 and KISS1R are modulated by estrogen receptor (ER) $\alpha$-mediated pathways play a critical role in breast carcinogenesis. ER level is consensually used as a prognostic marker of breast tumors and of the response to endocrine therapy [25]. Tamoxifen (TAM) administration upregulated KISS1 and KISS1R expression in ER-positive breast tumor cells.

Therefore, these findings seem to suggest that KISS1 expression level appeared to be an attractive molecular marker for predicting TAM responsiveness of ER $\alpha$-positive breast cancers, mainly in postmenopausal women. They also proposed a new model for ER $\alpha$-mediated modulation of KISS/KISS1R signaling, in which ER $\alpha$ expression is lost in breast epithelia as breast cancer progresses, and the brake keeping KISS/KISS1R signaling in check is removed, resulting in increased signaling through KISS1R, as well as increased induction of epithelial-to-mesenchymal transition in the mammary epithelial cells and acquisition of a mesenchymal phenotype, required for metastasis.

To conclude there is existences of strong prove to substantiate the molecular and functional features of KiSS 1 expression system in a breast cancer models and these studies suggest that KiSS-1 system may participate in fundamental role of tumor biology and metastatic process; therefore, targeting KiSS-1/GPR54 system may represent a novel therapeutic agents for the treatment of metastatic cancer patients. Further investigation is essential to elucidate the complex pathways regulated by the Kisspeptins and how these pathways integrate in the suppression of metastasis across range of cancers.

\section{REFERENCES}

[1] Zhou, P. \& Recht, A. Young age and outcome for women with early-stage invasive breast carcinoma. Cancer. 101(6):1264-1274 (2004)

[2] American Cancer Society: Cancer statistics 1998. CA Cancer J Clin 48: 1-63(1998).

[3] Chambers AF: The metastatic process: basic research and clinical implications. Oncol Res 11: 161-168, (1999).

[4] Yoshida BA, Sokoloff M, Welch DR and Rinker-Schaeffer CW: Metastasis-suppressor genes: a review and perspective on an emerging field. J Natl Cancer Inst 92: 1717-1730(2000)

[5] Stafford LJ, Vaidya KS, Welch DR. Metastasis suppressors genes in cancer. Int J Biochem Cell Biol, 40, 874-91(2008)

[6] Lee JH, Miele ME, Hicks DJ, Phillips KK, Trent JM, Weissman BE, Welch DR. KISS1, a novel human malignant melanoma metastasis suppressor gene. J Natl Cancer Inst, 88(23), 17311737(1996)

[7] Lee JH, Welch DR. Identification of highly expressed genes in metastasis-suppressed chromosome 6/human malignant melanoma hybrid cells using subtractive hybridization and differential display. Int J Cancer, 71(6), 1035-1044. (1997) 
[8] Ohtaki T, Shintani Y, Honda S, et al. Metastasis suppressor Kiss-1 encodes a peptide ligand of a G-protein-coupled receptor. Nature, 411(6837), 613-617(2001)

[9] Stafford LJ, Xia C, Ma W, Cai Y, Liu M. Identification and characterization of mouse metastasis-suppressor KiSS1 and its G protein-coupled receptor. Cancer Res, 62(19), 5399-5404 (2002)

[10] Harms JF, Welch DR, Miele ME. KISS1 metastasis suppression and emergent pathways. ClinExp Metastasis, 20(1), 11-18 (2003)

[11] Harms, J. F., Welch, D. R. Miele, M. E. KISS1 metastasis suppression and emergent pathways. Clin. Exp. Metastasis 20, 11-18 (2003)

[12] Stark AM, Tongers K, Maass N, Mehdorn HM, Held-Feindt J. Reduced metastasis-suppressor gene mRNA-expression in breast cancer brain metastases. J Cancer Res ClinOncol, 131(3), 191198 (2005)

[13] Ikeguchi M, Yamaguchi K, Kaibara N. Clinical significance of the loss of KiSS-1 and orphan Gprotein-coupled receptor (hOT7T175) gene expression in esophageal squamous cell carcinoma. Clin Cancer Res, 10(4), 1379-1383. (2004)

[14] Yu GZ, Wang JJ, Cheng Y, Canrong Ni. Significance of KiSS-1 and S100A4 in the process of metastasis of gastric carcinoma. Chinese-German J ClinOncol, 5(6), 388-390 (2006).

[15] Ohtaki T, Shintani Y, Honda S, Matsumoto H, Hori A, Kanehashi K, Terao Y, Kumano S, Takatsu Y, Masuda Y, Ishibashi Y, Watanabe T, Asada M, Yamada T, Suenaga M, Kitada C, Usuki S, Kurokawa T, Onda H, Nishimura O, Fujino M. Metastasis suppressor gene KiSS-1 encodes peptide ligand of a G-protein-coupled receptor. Nature, 411(6837), 613-617(2001).

[16] Masui T, Doi R, Mori T, Toyoda E, Koizumi M, Kami K, Ito D, Peiper SC, Broach JR, Oishi S, Niida A, Fujii N, Imamura M. Metastin and its variant forms suppress migration of pancreatic cancer cells. Biochem Biophys Res Commun., 315 (1), 85-92(2004).

[17] Mitchell DC, Abdelrahim M, Weng J, Stafford LJ, Safe S, Bar-Eli M, Liu M. Regulation of KiSS-1 metastasis suppressor gene expression in breast cancer cells by direct interaction of transcription factors activator protein-2alpha and specificity protein-1. J Biol Chem, 281(1), 51-8 (2006).

[18] Bari R, Zhang YH, Zhang F, Wang NX, Stipp CS, Zheng JJ, Zhang XA. Transmembrane interactions are needed for KAI1/CD82-mediated suppression of cancer invasion and metastasis. Am J Pathol, 174(2), 647-660(2009).

[19] Sanchez-Carbayo M, Capodieci P, Cordon-Cardo C. Tumor suppressor role of KiSS-1 in bladder cancer: loss of KiSS-1 expression is associated with bladder cancer progression and clinical outcome. Am J Pathol, 162(2), 609-617(2003).

[20] Shengbing Z, Feng LJ, Bin W, Lingyun G, Aimin H. Expression of KiSS-1 gene and its role in invasion and metastasis of human hepatocellular carcinoma. Anat Rec (Hoboken), 292(8), 11281134(2009).

[21] Martin TA, Watkins G, Jiang WG. KiSS-1 expression in human breast cancer. ClinExp Metastasis.22 (6): 503-511 (2005)

[22] Xie F, Yang H, Wang S, Zhou B, Tong F, Yang D, Zhang J. A logistic regression model for predicting axillary lymph node metastases in early breast carcinoma patients. Sensors (Basel). 12: (7). 9936-9950 (2012).

[23] Ulasov IV, Kaverina NV, Pytel P, Thaci B, Liu F, Hurst DR, Welch DR, Sattar HA, Olopade OI, Baryshnikov AY, Kadagidze ZG, Lesniak MS. Clinical significance of KISS1 protein expression for brain invasion and metastasis. Cancer.; 118: 2096-2105 (2012).

[24] Stark AM, Tongers K, Maass N, Mehdorn HM, Held-Feindt J. Reduced metastasis-suppressor gene mRNA-expression in breast cancer brain metastases. J Cancer Res Clin Oncol. 131(3), 191198 (2205)

[25] Clarke RB, Anderson E, Howell A. Steroid receptors in human breast cancer. Trends Endocrinol Metab. 15(7), $316-323$ (2004) 